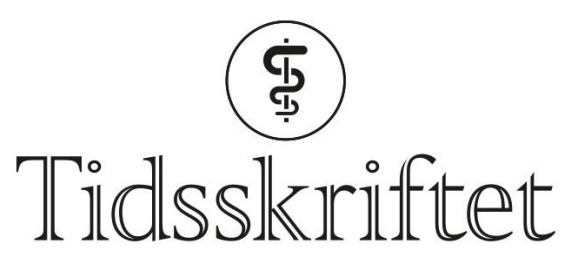

DEN NORSKE LEGEFORENING

\title{
Murphy's Law (med apostrof) eller skjebnens ironi (uten)?
}

KOMMENTAR

\section{MARK BERTHOLD-LOSLEBEN}

E-post: mark.berthold@losleben.eu Mark Berthold-Losleben er lege. Ingen oppgitte interessekonflikter.

Takk for en interessant artikkel (1). Erlend Hem skriver i artikkelen "Adam-Stokes' syndrom», med referanse til syndromet oppkalt etter R. Adams og W. Stokes.

Da heter det sannsynligvis enten Adams'-Stokes' syndrom eller Adams-Stokes' syndrom. Eller kanskje bare Adams-Stokes syndrom? Selv om regelen at genitiv lages med apostrof, dersom ordet allerede ender på -s, er lik på engelsk og på norsk, så skriver man på engelsk, så vidt jeg vet, Adams-Stokes syndrome (eller Cheyne-Stokes respiration) helt uten apostrof. Et alternativ for å unngå en apostrof kunne være å skrive Adams-Stokes-Morgagnis syndrom, men da vet man på slutten virkelig ikke lenger, hvem som ble født med en -s og hvem som fikk bare en sånn genitiv ending. Og egentlig er rekkefølgen uansett omvendt og det blir da ikke mer oversiktig. Hvor lander vi da, på Morgagni-Adams-Stokes syndrom, MorgagniAdams-Stokes' syndrom eller Morgagnis-Adams'-Stokes' syndrom?

\section{LITTERATUR:}

1. Hem E. Donders eller Donders' metode? Tidsskr Nor Legeforen 2017; 137: 1723.

Publisert: 12. desember 2017. Tidsskr Nor Legeforen. DOI: 10.4045/tidsskr.17.1011

(C) Tidsskrift for Den norske legeforening 2020. Lastet ned fra tidsskriftet.no 